\title{
A BUSCA DA LINGUAGEM NA MUDEZ DOS INCÊNDIOS EM LÍDIA JORGE E CLARICE LISPECTOR
}

\author{
Ana Maria Vasconcelos Martins de Castro \\ (Universidade Federal do Rio de Janeiro)
}

\section{RESUMO}

Deparamo-nos, no conto "Marido", de Lídia Jorge, e na peça "A pecadora queimada e os anjos harmoniosos", de Clarice Lispector, com duas mulheres que, se viveram abafadas, encontram na morte uma última e dolorosa possibilidade de fala e de poder. Se é verdade que ambas morrem numa luta inglória e desigual com o masculino, também é patente o esforço por encontrar, da sombra à qual foram subjugadas, um lugar onde a respiração seja possível no mundo falocêntrico,

PALAVRAS-CHAVE: Silêncio, Lídia Jorge, Clarice Lispector

\section{ABSTRACT}

In Lídia Jorge's short novel "Marido" and in Clarice Lispector's play "A pecadora queimada e os anjos harmoniosos" we see two female characters who certainly lived without a voice and finally found in death their last and painful possibility of having a speech. If it is true that they both die in an uneven struggle with male's power, it is also clear their effort to search, from the shadows, a place where some breathing is possible in this phallocentric world.

KEY WORDS: Silence, Lídia Jorge, Clarice Lispector 
"Quereria falar a Deus, abrir-se toda a Ele; mas com que linguagem?"

O primo Basílio, Eça de Queirós

"No teatro, o silêncio expressa-se através de sons e não pela sua ausência."

Carta de Stanislavski para Tchecov em 10/09/1898

Há fogo. Há muita fumaça. Pela pele, pelos cabelos, pelos pulmões das personagens. E há silêncio - mas este sempre houve. Mesmo antes de a porteira e a pecadora morrerem. Em vida, nunca lhes fora possível ter um discurso próprio, uma voz. As gargantas de ambas há muito já sufocavam, mas por culpa de outra fumaça: o masculino.

Também nós silenciamos ao terminarmos de ler o conto "Marido", de Lídia Jorge, e a peça "A pecadora queimada e os anjos harmoniosos", de Clarice Lispector. E quem nos cala já não é o homem na sua dimensão opressora, mas o feminino, em toda a sua força de resistência, em sua tentativa de fuga da mão viril, que abafa e queima. É diante do percurso da mulher nessas duas obras que a palavra inevitavelmente se torna pouca e pequena. Tentaremos alargá-la neste trabalho.

\section{A FUMAÇA, O FOGO E O SILÊNCIO FUNDADOR DE LUIZA}

Estamos diante de duas protagonistas construídas de maneira bem diversa, mas cujas trajetórias, mais do que culminarem igualmente numa cruel fogueira humana - semelhança que, veremos, não é meramente imagética -, aproximam-se tanto naquilo que dolorosamente lhes falta (o discurso) quanto naquilo que, com igual angústia, pesa terrivelmente sobre elas (o poder acachapante do masculino).

Proferida por Luiza, a "indagação fundadora" de O primo Basílio que abre este trabalho ressoa na questão fundamental das personagens que aqui vamos analisar: o lugar de silenciamento. Tal frase, lembremos, é de um texto de Eça de Queirós, autor que, com todo o seu "pudor anti-romântico" (Coelho, 1977, p. 165), jamais a colocaria levianamente na boca de qualquer personagem, especialmente quando o tom de gravidade da cena contrasta tanto com quase todo o resto da irônica narrativa (exceto algumas raras passagens, justamente ligadas ao feminino silenciado, como a própria morte de Luiza). Ao pontuar a trajetória de Luizinha - e aqui o diminutivo é mais uma das formas pelas quais o masculino imbeciliza o feminino - com essa até então inesperada crise de consciência, Eça de Queirós dá à sua personagem uma dimensão de falência do eu muito mais cruel. Se antes Luiza era talvez vista pelo leitor como frívola, superficial, tola, agora ela é incontornavelmente reconhecida como idiotizada, diminuída, silenciada - ou seja, paciente da ação do outro. Luiza nunca fora uma mulher estúpida: era uma mulher, e, por isso, estupidificada. Como nos 
ensina Monica Figueiredo (2002), seu grande crime havia sido justamente o de não aceitar este emparedamento e ousar desejar para fora dos limites que o masculino lhe impusera. Luiza não poderia senão falhar nessa tentativa, justamente por não ter podido aprender a locomover-se fora do lugar que lhe fora imposto; por nunca ter tido voz.

Deparamo-nos, então, com uma Luiza pela primeira vez a enxergar claramente a própria condição, com uma lucidez dolorosa. Ao se questionar "com que linguagem?", a personagem faz esta pergunta sintomaticamente pela voz do narrador: "Quereria falar a Deus, abrir-se toda a Ele; mas com que linguagem?” (Queirós, 2008, p. 342), recurso que encontraremos também tanto em "Marido" quanto, com a adaptação necessária, em "A pecadora queimada e os anjos harmoniosos". ${ }^{2}$ As três obras se articulam sob este aspecto, acreditamos, exatamente pelo mesmo motivo: a falta de um discurso próprio dessas mulheres. Aqui chegamos à dupla importância desta frase como epígrafe deste estudo, o que justifica nos determos tanto tempo nela antes de entrarmos de fato na análise do nosso corpus. Além de a frase de Luiza representar um questionamento norteador para a nossa análise, a falta de linguagem, a forma pela qual é enunciada - pela outra voz, a do narrador - aponta mais gravemente para a dimensão do silêncio e do silenciamento que vamos abordar.

A personagem de Eça teve a sua crise de consciência talvez justamente porque intuísse que não se tratava de uma incapacidade sua de ter um discurso seu, mas de um desconcerto do mundo que, perversamente falocêntrico, negara-lhe o direito de dizer. Eça de Queirós retratou o grande crime das mulheres do século XIX: desejar para além do que lhes era permitido. Do mesmo modo, entendemos, ocorre às personagens de Clarice Lispector e Lídia Jorge. Trazendo a discussão para o século XX, as duas mulheres aqui estudadas sofrem agudamente de um silenciamento oriundo de uma opressão do masculino. Tal como Luísa, elas estão emparedadas e abafadas, impedidas de possuir uma linguagem própria. Veremos então de que modo agem essas mulheres a partir de tal imposição, e se há algum sucesso possível nessas investidas gaguejantes.

\section{A PAISAGEM AUDITIVA DO INCÊNDIO MUDO}

Ainda sobre as epígrafes, outra imagem que nos parece poderosa e bastante metafórica do eixo problemático das obras trabalhadas aqui é a do cenário sonoro em Stanislavski. Os elementos auditivos eram utilizados por ele para fazer o silêncio poder aparecer nas suas montagens. Sobre isso Roubine (1998, p. 155) nos diz que o diretor russo, entendendo o teatro como o espaço daquilo que chamou de paisagem auditiva, resolveu o problema da representação do silêncio na peça A gaivota, de Tchecov, utilizando coaxar de sapos como elemento contrastante.

Ora, se no teatro o silêncio expressa-se através de sons e não pela sua ausência, o que vemos acontecer em "Marido" e em "A pecadora quei- 
mada..." não é diferente. Se o barulho é o recurso utilizado para construir a sua falta - o silêncio - que, de outra forma, não se manifestaria com tamanha intensidade, a correlação com os textos aqui analisados nos parece perfeitamente cabível. Para que o silêncio do feminino apareça, é necessário que se exponha algum ruído contrastante.

Podemos dizer, nessa comparação, que em Lídia Jorge o som dos grilos são os gritos do marido bêbado e a interferência dos vizinhos. Mas se analisarmos com mais cuidado, veremos o que mostra com mais ênfase o silenciamento de Lúcia: a voz narrativa. Como veremos a seguir, essa voz se localiza espacial e afetivamente junto à porteira, como numa forma de realizar em texto aquilo que a personagem não consegue em vida. Nesse sentido, o som dos grilos é, em última instância, além da voz narrativa - aquela que fala enquanto (e na vez de) a protagonista (que) silencia -, a própria forma simulada pelo texto: a oração, a ladainha. A oração às avessas é a linguagem problemática que aparece no lugar do silêncio imposto à porteira, é o grilo que canta mais alto no conto porque canta o tempo inteiro.

O coaxar incessante dos sapos, para usarmos agora outra imagem auditiva de Stanislavski, são os homens na peça de Clarice - amante, marido, sacerdote, guardas -, vozes que falam excessivamente, apontando assim, no contraste, para a mudez da pecadora. Mas também aqui podemos sentir outro nível da paisagem auditiva: mais grave do que as vozes masculinas é a única voz feminina a ser emitida na encenação, a voz da Mulher do Povo. Ela e a Criança com Sono representam o coaxar dos sapos por espelharem, como rubricas, os passos da pecadora: quando ela entra, repetem "ei-la" e, quando ela sorri, são eles que notam e dizem isso ao público. Aliás, é o sorriso da pecadora - única ação da protagonista durante a peça - talvez o gesto que mais eloquentemente nos mostre o profundo silêncio daquela mulher. É porque esse breve e significativo sorriso aparece para o leitor (plateia) que se sente com tanta intensidade que em momento nenhum brota daqueles lábios dolorosamente sorridentes uma voz.

A paisagem auditiva para a qual chamamos atenção aqui é importante por representar a única linguagem possível dessas personagens que não possuem um discurso próprio, e é justamente a linguagem de certa forma gaguejante - esta a que aparece - que consegue passar o silêncio de forma tão eficaz para o leitor.

\section{A PORTEIRA E A EXTERIORIDADE DA PRÓPRIA VOZ}

Desde o título, percebemos em "Marido" a força da dominância opressora do masculino. O feminino aparece como uma sombra, como aquela que existe precisamente porque tem um marido. Ressaltemos aqui que o título de "A pecadora queimada e os anjos harmoniosos" não deixa de trazer a marca da subjugação que o feminino sofre, afinal a mulher sempre foi, historicamente - e ainda é, culturalmente -, culpabilizada pelo pecado. Mas o título "Marido", contendo unicamente o posto do homem 
sem qualquer adjetivo ou artigo, esse título nos parece por isso mesmo ainda mais eloquente. Ele é mostrado enquanto ela está à sombra: a posição é masculina, pressupondo um feminino atrelado e escondido, que só aparece no nome do conto enviesadamente (um marido pressupõe uma esposa). Assim também é o modo pelo qual tentará aparecer a voz da porteira ao longo da narrativa.

Bastante reveladoras são as denominações dadas às personagens deste conto. Vemos o advogado, o médico, a assistente social, o padre - todos nomeados conforme o trabalho ou cargo que exercem. Mesmo Lúcia, nós a conhecemos primeiro como a porteira. Mas o marido, não. O marido não é nunca denominado o mecânico: é marido apenas, pleno na sua condição de homem possuidor de uma mulher. Além de o título trazer uma carga semântica de coisa definitiva e totalizante, esta mesma denominação ao longo do conto parece igualmente mostrar o poder do homem: este o de ser marido.

Ainda em relação aos nomes, o leitor só conhece o de Lúcia porque ele é pronunciado num grito ameaçador do marido, sintomaticamente o único personagem do texto a possuir uma fala propriamente sua. À porteira cabe apenas imaginar a voz a que nunca teria direito: "Se ele vier na volta da madrugada, até mesmo se já for dia, ela lhe dirá - Ah, como nos quiseram separar! Ainda tremo, marido!” (Jorge, 1997, p. 21, grifo nosso). Crucial este trecho, um dos dois únicos em que a voz que Lúcia teria aparece - e é imaginária, hipotética, num futuro somente vislumbrado. A fala que lemos, portanto, não é de Lúcia, porque ela nunca a teve. Vejamos ainda outro trecho do conto no qual a porteira, censurada, canta baixo para não despertar os inquilinos: "Não os pode perturbar. Só mexe os lábios - Regina misericordiae" (p.15, grifo nosso). A imagem da reza muda é o quadro da opressão vivenciada por Lúcia, do seu sufocamento existencial. Observe-se que nesta segunda cena não é o marido quem a cala, mas os próprios moradores do prédio onde ela trabalha e vive. Estamos diante de uma mulher que não consegue falar senão num futuro hipotético, que não consegue cantar senão baixinho, que não consegue sequer rezar senão apenas enclausuradamente movendo a boca sem produzir som nenhum.

"Que ideia triste aquela de a assistente social dizer que uma mulher é um ser completo" (p. 18), pensa a porteira através da voz narrativa. E com ela entendemos a dimensão cruel da lucidez da própria falência: saber-se alguém que não consegue sequer ser. Entendemos que esta frase conversa diretamente com a de Luiza. É o mais próximo de uma crise de consciência que a porteira consegue chegar, e ainda assim é uma enunciação às avessas, porque não questiona diretamente a própria situação, ao contrário, ratifica a sua condição de inferioridade. No entanto, o absurdo da radicalidade da sentença nos choca de tal forma que nos vemos diante de uma crise do eu, mas como que encoberta por uma fumaça. Afinal a frase que a porteira nunca foi capaz de emitir e que estaria dizendo por baixo da que pensou é: "nunca me ensinaram a ser inteira". Ou: "nunca me 
disseram que eu poderia ser inteira". Ou: "nunca me disseram que eu sou inteira”. É como se Lúcia apenas circundasse estas ideias porque, de fato, nunca poderia pensá-las, não tendo ferramentas - linguagem - para isso.

O recurso de se dizer às avessas está presente por todo o texto. A invocação de Lúcia à Regina é construída na direção semanticamente oposta à esperada: se numa oração pede-se uma intervenção divina no sentido de libertar alguém, salvá-lo, curá-lo etc., a voz narrativa pede: "abafa a vida", "não me desconfines", "acocora-te [sobre a porteira]" (p. 11). O abafamento e a escuridão são implorados porque é com esta outra forma de clausura que se escapa da primeira cela: "Mater misericordiae, abre as asas, abafa o som do coração da porteira, apaga da vista do marido dela a luz que possa iluminar o ângulo escuro onde a porteira está escondida." (p.14). Prisão sucedendo prisão: este é o movimento sufocante do conto. Oprimida pelo masculino, só o outro abafamento - o do feminino - poderá salvá-la.

A oração às avessas pede para sufocar, para abafar e ainda algo mais grave:

Claro que ele precisa de protecção, antes, depois e durante, porque sempre se está em perigo numa oficina-auto. Imenso perigo porque tem de se deitar sob carros inteiros e peças resvaladiças, o corpo completo no chão, a cabeça sob os motores, os olhos sob as alavancas mais que perigosas. (p.12)

Testemunhamos a voz narrativa demorar-se nas minúcias do perigo que corre o marido - nada diferente de um agouro. Imaginar um ser amado em situação de grave risco causa uma repulsa imediata que beira o insuportável: repele-se rapidamente qualquer pensamento que se insinue numa transfiguração da cabeça do amado sob motores antes mesmo que ele de fato chegue a montar tal imagem. Seguir esse pensamento é, portanto, um modo de desejá-lo. Vejamos a continuação do texto:

Além disso, o marido da porteira tem um vinho erecto, porque quanto mais toma mais perfila as pernas, a coluna e o corpo todo. O que em princípio não deveria constituir um perigo, mas constitui. Com as pernas desse modo esticadas, fica sujeito a bater com a cabeça numa esquina, a encalhar num lancil, a esfacelar o braço, a ir de encontro a um carro e ser atropelado. (p.13)

Ora, aqui como que se justifica o desejo - às avessas, insistimos - de que o marido corra perigo: o vinho que ele bebe não o deixa cambaleante, mas ameaçadoramente mais viril, mais homem, porque seu vinho é erecto. O perigo de que se fala no trecho acima diz respeito, em último grau, à própria porteira nas mãos deste homem rígido de álcool. O risco que o marido é aquele que efetivamente ele deveria correr segundo o desejo da porteira, agora ameaçada. Novamente observamos uma sucessão de imagens de desastre que, além de fortes individualmente, constituem 
uma gradação intencionalmente excessiva por extrapolar o esperado três, desdobrando-se assertivamente num quarto elemento significativamente mais longo do que os anteriores (compare-se a força de "ir de encontro a um carro e ser atropelado" em relação a "bater com a cabeça numa esquina", "encalhar num lancil" e "esfacelar o braço"). Insistimos na violência das imagens, representativas da vontade de sangue que Lúcia não ousaria expressar sequer para si própria. Como nos diz Eni Orlandi, em seu livro As formas do silêncio, não é necessariamente pela ausência de palavras que o silêncio aparece:

Impor o silêncio não é calar o interlocutor mas impedi-lo de sustentar outro discurso. Em condições dadas, fala-se para não dizer (ou não permitir que se digam) coisas que podem causar rupturas significativas na relação de sentidos. (Orlandi, 2007, p. 102)

A porteira não está senão impedida, por aquilo que aprendeu como normalidade do mundo, de rejeitar o marido violento. Valendo-se da única linguagem que conhece, a oração, Lúcia experimenta a perversidade que não consegue frear por completo. Se só lhe ensinaram a cuidar do homem, é isso o que ela vai fazer - às avessas. De modo que a ladainha inicialmente monótona vai sombriamente se adensando numa forma velada de expressar o seu desejo inconfessável.

Se é o marido quem, na visão deturpada da porteira, a faz existir socialmente - ser inteira -, não há, em seu horizonte, nenhuma possibilidade de divórcio. O único modo de existir conhecido por ela passava com e pelo marido. A crueldade do fardo imposto à mulher do "até que a morte os separe" se redime na última e sofrida salvação: "agora e na hora de nossa morte".

É depois de conhecermos a figura execrável do marido que avistamos outro lampejo significativo da verdadeira vontade interior da protagonista: "a porteira sabe, nunca dará um passo para se separar do marido. Pensando nisso, chega a sentir um sentimento incristão." (p. 20) Apesar de consciente da própria condição, a porteira não tem mãos de afastar o marido nem pés de fugir dele, todo o seu corpo está imobilizado. E, dolorosamente, disso ela sabe. É sabendo, portanto, do próprio emparedamento que ela caminha para a ascese na morte, a sua única saída. O sentimento incristão já povoa o texto desde o seu início, na forma velada de agourar o marido, na oração às avessas.

Somente o feminino poderia salvá-la. Talvez por isso o nosso primeiro impulso seja o de dizer $a$ narradora, em vez de naturalmente $o$ narrador do conto. Para além da sua colagem espacial e afetiva com a protagonista, intuímos que somente uma voz de mulher poderia servir-lhe de garganta e doar-lhe o discurso ao qual nunca teve acesso. A voz narrativa, desse modo, exerce o papel de uma espécie de duplo da porteira, uma vez que esta - um meio-ser - não seria capaz de, por si própria, afirmar-se. É 
como se a protagonista só conseguisse dizer de si por meio dessa voz que, se é um duplo próximo, é também inegavelmente um outro, e, portanto, um exterior.

Listemos alguns dos exemplos em que flagramos a voz narrativa exercendo a função do duplo (dotado de linguagem) da porteira (emudecida). Ao dizer "protege da aragem a chama da vela até ele vir" (p.11, grifo nosso), a narradora localiza-se ao lado de Lúcia, em sua casa (seria exagero dizer: em sua boca?). Lemos ainda: "Mas deveria vir logo para casa" (p. 12, grifo nosso), “Já o marido vem." (p. 22, grifo nosso). Esta relação entre voz narrativa e personagem, no entanto, ganha uma dimensão mais complexa. Há um movimento tanto de 1) aproximação, colagem e indiscernibilidade quanto de 2) afastamento, descolamento e distanciamento cinematográfico:

Imaginar a cara do marido sob uma roda em andamento provoca uma angústia vespertina na porteira. Por isso mesmo ela chama a Regina para lhe tirar a angústia e proteger o marido, antes de a proteger a ela e à casa. Proteger o trajecto, a porta, a casa, até ele vir e depois de ele vir, às sete. (p. 13, grifos nossos)

Além de observarmos mais uma vez a narradora situar-se espacialmente, aqui ficamos sabendo que é a própria Lúcia quem pede proteção divina. Ora, quem abre o conto pedindo esta mesma proteção não é a voz narrativa? Lembremo-nos de que ao dizer "Protege- $a$ bem." (p. 12, grifo nosso), o texto separa narrador e personagem. Como se dissesse: "proteja ali, proteja aquela que não sou eu”. É um verdadeiro jogo de enlace e desenlace de corpos, ora uno, ora duplo, ora apartado.

Ainda sobre essa frase, "Protege-a bem., é preciso dizer que ela, sozinha, constitui um parágrafo inteiro. Com isso Lídia Jorge nos diz: prestem atenção. Proteger a porteira é a ação mais preciosa a ser realizada no conto, e, destacada dessa maneira, a sentença ganha uma dimensão mais grave. O parágrafo seguinte é uma tentativa de explicação do que significa protegê-la - do quê e por quê -: "Protege-a bem, a ela e ao marido dela" (p. 12). É com este arranjo que Lídia Jorge nos diz que proteger a porteira é igual a proteger a porteira e o marido. Ou uma equação ainda mais triste: a porteira é igual a a porteira mais o marido. Porque é essa a ideia de Lúcia, insistimos, a de que é o marido quem lhe dá existência. Voltamos à ideia - que, nos parece, é central nesse que é um texto sobre o emudecimento existencial - já apresentada de que é o discurso do marido que nomeia Lúcia e que ela, por sua vez, não consegue nomeá-lo, a sua afasia é resultado do medo enorme deste intransponível masculino.

O parágrafo mencionado, então, segue explicando por que se pede proteção para este tão precioso marido. Também aqui encontramos o recurso de dizer pelo avesso: o tal grande risco que o marido corre não é um perigo real. Pelo contrário, o que se nos mostra é o perigo desejado pela porteira. Um pouco depois lemos os motivos pelos quais um homem é imprescindível na vida de uma mulher: 
E quem atarrachava as lâmpadas do tecto? Quem tinha força para empurrar os móveis? [...] Quem desarmava a cama, empurrava o frigorífico, consertava o carro quando avariava, reclamava com o criado com voz grossa quando saíam para comer caracóis à beira-mar? [...] Quem faria todas aquelas coisas importantíssimas? Que papel imprescindível, que pessoa necessária na vida da porteira. (p.18)

E a lista se estende longamente. Ora, reservar quase duas das catorze páginas do conto para supostamente enumerar as incontáveis razões pelas quais sem este homem, no alto da sua suprema importância, Lúcia seria um ser incompleto e preenchê-las com minúcias de ações absolutamente banais é de uma ironia angustiante. Mais uma vez constatamos que a porteira não tem voz para dizer a real (falta de) importância daquele homem, somente um balbucio de exaltação do patentemente execrável. É no descompasso entre o que se enuncia e o que se constata que o discurso silenciado daquela mulher pode ser escutado. Retomamos aqui as nossas epígrafes: é no contraste que o silêncio pode ser identificado, e é esta a linguagem possível dessa mulher.

Mas analisávamos o jogo de encaixe e desencaixe dos pontos de vista da voz narrativa e da protagonista. Passamos pela colagem absoluta e pelos graus de aproximação e afastamento, porém o distanciamento total é ainda um elemento interessante a ser comentado. Várias vezes ao longo do texto percebemos um efeito quase cinematográfico, como neste trecho:

Já ela o ouve tocar, depois subir, abrir a porta do elevador com dificuldade, sair de lá lentamente com o pé rígido, e depois a chave começa a cair junto da porta, sente levantá-la do chão, deve estar a revolver a chave, até que por fim ele a enfia, a roda, a desprende, a saca, fica dentro de casa e a casa se enche do seu hálito até às bacias e às janelas. (p. 13-14, grifo nosso)

Além de todo o percurso ser narrado como um plano-sequência, o efeito de audiovisual aparece com muita força quando o texto diz que a chave começa a cair. A câmera lenta, além de recriar a atmosfera de terror vivenciada por Lúcia, articula-se pungentemente com o verdadeiro abuso simbólico que é o encadeamento, ainda sobre a chave como elemento fálico, em "a enfia, a roda, a desprende, a saca", mais uma vez trazendo o feminino violado na sua imobilidade. A construção da câmera lenta - e, portanto, do distanciamento radical da outrora junção indiscernível entre voz narrativa e personagem - aguça o horror da cena. Entrar na casa é um estupro. Encher a sala com seu bafo repulsivo é jorrar brutamente o líquido viril na cavidade frágil da porteira.

É também cinematográfica a narração da morte de Lúcia:

Já o marido vem. Exacto. Já tocou, agora subiu, agora rodou a chave, já caiu, já apalpou, já abriu a porta e ela já está a pé. Marido? Tal como ela pensou, ele parece 
estupefacto por vê-la. Parado entre as portas, com os olhos bem abertos a olhá-la. Marido? (p.22)

Testemunhamos a presença de uma voz originada por duas bocas, uma mescla entre a narradora e a porteira, uma vez que não há travessões indicando que esta é uma fala própria de Lúcia. No discurso indireto livre, a pergunta gaguejante de Lúcia é delegada à voz narrativa, e esta, ainda assim, tristemente só consegue dizer: "Marido?" e nada mais. Um abafamento total toma conta da cena: "tudo sem ruído [...]. Mesmo a chave que cai não faz barulho, como numa cena longínqua, aproximada, a que se tirou todo o som" (p. 22). A voz narrativa então nos mostra distanciadamente, como um diretor de cinema, o homem de Lúcia: "Vejam como ele se vira, como o seu cabelo curto de homem lhe cai pela testa, como é bonito o lábio roxo do marido, sem som, só bafo." (p. 22). Invocando a figura de uma plateia, o texto, cada vez mais cinematográfico, situa-nos na posição de espectadores. Estaríamos nós, leitores, ocupando o papel que antes fora dos vizinhos? O de espreitar o que se passa na casa da porteira? E, como num espelho que revela o lado oposto, diferentemente do barulho humilhante das agressões que os inquilinos testemunharam, o que nos é mostrado constitui uma cena muda de purificação? Parece-nos que sim. E o marido sem som? É já o milagre da Regina que culminará na derradeira libertação?

Também a agonia de Lúcia é narrada cinematograficamente: a monotonia abafada da ladainha inicial - a invocação - culmina na câmera lenta agonizante da cena do homicídio-suicídio - a intervenção -, que escoa para o clímax do conto nas suas exclamações mudas. Percorremos a gradação da agonia de Lúcia: primeiro o seu olfato havia sido sufocado com a fumaça da vela, depois sua visão fica completamente turva, então há o abafamento dos ouvidos e, por fim, o terrível descolamento do tato, numa nova gradação dolorosa em direção à radicalidade do eu: o fogo queima a camisa, incendeia o cabelo e, enfim, desprende a pele. Não nos escapa a ideia de o paladar, sentido não mencionado diretamente por Lídia Jorge na morte da sua personagem, estar representado justamente na linguagem faltante à porteira, na sua língua queimada.

\section{A PECADORA SILENCIOSA E A AFASIA DO PERDÃO}

Depois de observarmos o esfacelamento dolorosamente literal de Lúcia, passemos agora a outra morte cruel e redentora, a desta mulher anônima cuja carne assada vai matar a fome de espetáculo do povo: "Não compreendemos, não compreendemos e temos fome de carne assada." (p. 189).

Em "A pecadora queimada e os anjos harmoniosos", Clarice nos dá personagens não nomeados. Tal como vemos em "Marido" - o advogado, o marido, a porteira -, o que aparece nesta peça são os papéis sociais, não uma individualização psicológica, não um nome. Assim ouvimos o Esposo, o Amante e o Sacerdote falarem sobre a Pecadora. 
Sem nome, sem carne e sem voz, esta mulher, em princípio, personificaria a imagem da humilhação e da inferioridade, seria a representação da mulher sujeitada. No entanto, Clarice não nos oferece um quadro sociológico puro e simples, mas, com sutil refinamento, um vislumbre estreito, é verdade (justamente porque o controle daquele mundo pertence às mãos masculinas), mas ainda assim real - da superioridade feminina. A pecadora guarda uma força interna, um centro imaculável que não a deixa vergar-se em meio à tragicidade - e ao absurdo - da sua condenação fatal.

A protagonista da peça não tem fala e no entanto é o único assunto e quase o único eixo de atenção de todos os outros personagens. Se esse jogo aparenta exemplificar uma reificação do outro, percebemos, através do deslocamento valorativo, que tal primeira impressão é extrapolada: aquela mulher é sim objeto do discurso masculino, mas este discurso é amoroso. ${ }^{3}$ Portanto, se é verdade que este feminino torna-se coisa (apartada de sua integridade humana, a pecadora é brutalmente impedida de ter direito ao seu corpo, à sua vida), também é fato que esta coisa é preciosa.

Se os homens detêm o monopólio das falas na peça, o assunto é sempre - e amorosamente - ela: "ah, esposa ainda amada" (p. 182); "AMANTE: Pela primeira vez, amo. Eu te amo" (p. 184); “Esposo: Pela primeira vez eu te amo, e não à minha paz" (p. 184) etc. E podemos dizer, ainda, que se essa mulher se torna objeto do discurso alheio, é igualmente verdade que, interessantemente, é esse mesmo discurso masculino que, compadecidamente, devolverá humanidade a ela, na medida em que reverbera a sua verdadeira condição: de injustiçada. Discutiremos esse curioso paradoxo em seguida.

Antes vejamos o Esposo, que, desde a sua primeira fala, inverte a direção da culpa, apontando-a para si próprio: "Ei-la, a que será queimada pela minha cólera. Quem falou através de mim que me deu tal fatal poder?" (p. 182). Ela será morta, portanto, não como consequência de um ato dela, mas por conta do ódio e do poder masculinos, que se manifestam através do Esposo. O Amante mais tarde flagrará o desconcerto daquela punição: "Ai de mim que não sou queimado. Estou sob o signo do mesmo fado mas minha tragédia não arderá jamais." (p. 189). Ele, que participou do mesmíssimo ato, sabe que sua tragédia não arderá jamais precisamente porque ele é um homem, e não é essa a carne que queima. É claro que a Pecadora morrerá não por pecar, mas precisamente por ser mulher, e isso o amante adivinha. O castigo se dá por ela se atrever a ser livre - e aqui podemos retomar Luiza, punida tragicamente por ousar desejar a liberdade a que o feminino não tinha direito.

Dissemos em nota que, por se tratar de um texto dramático, a ausência de um narrador que pudesse dar voz à Pecadora ou mesmo falar por ela agravaria o seu silêncio. Retomemos outra vez Eça de Queirós: em O primo Basílio, a crise de consciência de Luiza é proferida pela voz narrativa. Em "A pecadora queimada...", não havendo um narrador para falar 
por ela, a mulher estaria ainda mais só e mais silenciada. O movimento de Clarice Lispector de apagar simbolicamente a sua protagonista - de cuja presença tomamos ciência apenas por conta das rubricas - e de colocar seus movimentos nas falas dos outros personagens pareceria, numa primeira impressão, um exercício cruel de objetificação radical da Pecadora. Mas a disposição de mudez e fala na peça nos dão a ver os dois exemplos da monstruosidade apontada em Fragmentos de um discurso amoroso: "O outro fica desfigurado pelo seu mutismo [...]; e eu que falo também fico desfigurado: o solilóquio faz de mim um monstro, uma língua enorme" (BARTHES, 1981, p. 149). Possuir uma fala traz uma superioridade doentia aos homens, desfigura-os, flagrando assim a injustiça: o masculino é uma língua enorme enquanto o feminino não passa de uma boca amordaçada.

Mas não é verdade que ela "está tão sozinha" (p. 188) assim: a Criança com Sono nos avisa que a Pecadora "está sorrindo" (p. 186). Se ela não pode falar, e se o masculino não pode redimi-la, é a criança na sua assexualidade quem vai refletir para nós, público, o único gesto daquela mulher à beira da morte: um sorriso. Em seguida, o Esposo diz que os olhos dela estão brilhando "como numa glória" (p. 186). Ora, percebemos um esforço de ressaltar uma altivez, uma dignidade, uma superioridade daquela mulher que, a princípio, pensávamos estar humilhada e inferiorizada.

Voltamos aqui ao paradoxo do que chamamos de deslocamento valorativo: ao mesmo tempo que o feminino é transmutado em objeto (amoroso) - pelo masculino -, também é reassegurado em sua posição de sujeito - pelo ser sem gênero - na medida em que o seu gesto aparece na vez da sua voz. E se aquele sorriso só é visto por nós pelo aviso da criança é porque o masculino tolheu irrecuperavelmente seu direito à fala.

Sabemos que a Pecadora, apesar de principal, não é a única representação do feminino na peça. A Mulher do Povo é o seu duplo, que se levanta significativamente com sua voz crítica, dirigindo-se aos participantes daquela condenação absurda. Ela diz: "Ei-la, a que errou, a que para pecar de dois homens e de um sacerdote e de um povo precisou" (p. 181). O pecado, portanto, na visão lúcida do feminino, não aconteceu durante o ato mesmo da traição, mas somente a partir do exato instante em que a instituição detentora de poder acusa e condena. O pecado é, assim, relativizado no seu limite: se o castigo não fosse assinalado, o crime jamais teria sido configurado como tal. Vejamos ainda esta fala plurissignificativa: "Povo: Pois então escondia do esposo o seu amante, e do amante escondia o esposo? Eis o pecado do pecado." (p. 183). Aqui a colocação é dúbia porque na medida em que o povo a acusa duplamente no sentido mais direto da frase - pecou duas vezes, portanto -, no seu sentido mais amplo, levando em consideração toda a peça, esta fala apenas reforça o caráter contraditório daquela condenação, enfatizando o verdadeiro pecado: ser uma mulher.

Antes de nascerem, os Anjos Invisíveis dizem: “ainda não somos menino e menina” (p. 179), intuindo o peso futuro da sexualidade. A discussão sobre a inequidade dos gêneros cresce ao longo do drama num 
contraponto à noção, também dita pelos Anjos, da harmonia que deve ser preservada a todo custo. Esta sangrenta e terrível harmonia pressupõe a manutenção do processo estabelecido de punição do feminino que não se curva ao masculino. Podemos dizer sem equívoco que a temida harmonia é, de fato, o senso comum patriarcal e opressor que encerra a mulher no espaço do qual, se ela ousar tentar sair, ou falhará por não saber como ou será fatalmente punida. ${ }^{4}$

Mas mesmo no flagrante da desigualdade entre homens e mulheres, reconhecemos a fala do perdão masculino. Todos - Esposo, Amante, Sacerdote - dirigem-se à Pecadora com brandura, intencionalmente minimizando o dito crime. Não por acaso, isso quem nota é a Mulher do Povo, que irrompe: "Todas estas palavras têm estranhos sentidos. Quem é esta que pecou e mais parece receber louvor ao pecado?” (p. 184). No entanto, esse mesmo perdão não impede que se realize a morte daquela mulher, uma morte cruel, lenta, na fogueira e em praça pública para servir de exemplo às outras. Talvez isso se dê justamente pelo fato de não ter havido crime nenhum: se não houve pecado, o perdão é nulo. O que há para ser perdoado? O encontro natural de dois corpos? A liberdade sexual feminina? A aceitação do próprio desejo? Se nada disso configura um pecado - afinal ele só se instala na medida em que o Sacerdote, o Esposo e o Povo dizem que ele existe -, não cabe falarmos nos termos de crime e absolvição. De castigo, no entanto, é que se trata a peça. Com ou sem pecado, com ou sem redenção, o que está em jogo é que o povo tem fome e que a sangrenta harmonia deve ser mantida: queimem-na, portanto. Queimem-na já. Pouco importa o que se argumente:

Esposo: Como te reconhecer, se sorris toda santifica$d a$ ? Estes braços castos não são os braços que enganosos me abraçavam. E estes cabelos serão os mesmos que eu desatava? Interrompei-vos, quem vos diz é o mesmo que vos incitou. Pois vejo um erro e vejo um crime, uma confusão monstruosa: ei-la que pecou com um corpo, e incendeiam outro. (p. 187, grifos nossos)

Se a sua voz foi o bastante para a condenação da mulher, já nada pode fazer para salvá-la, porque não há caminho possível de retorno: "EsPoso: [...] O incitamento ao incêndio foi meu, mas não será minha a vitória: esta pertence agora ao povo, ao sacerdote, aos guardas" (p. 186-187). Mas depois de a fogueira virar cinzas, não haverá vitória, e os próprios guardas percebem: "10 e 2० GUARDAs: Exatamente como na guerra, queimando o mal, não é o bem que fica...” (p. 191). Não só o Esposo, mas também o Amante e o Sacerdote reconhecem-na uma pecadora sem pecado, e nada impediu que ela fosse atirada para arder na fogueira. Se há, portanto, nesta peça, uma afasia verdadeira, esta não é a da Pecadora sem pecado, mas a do perdão sem pecado.

Essa ausência estrutural reverbera em certas imagens, como na fala do Sacerdote: "Mas nem a cor é mais dela. É a de Chama” (p. 189); na do Esposo: "ei-la sorrindo, de mim ainda mais ausente do que quando era 
de um outro [...] pois eis que a tornei inatingível mesmo antes dela morrer" (p. 186); e na do Amante: "sorris inacessível [...]. Por que estranha graça o pecado abjeto transfigurou-te nesta mulher que sorri cheia de silêncio?" (p. 186). É a simultaneidade do apagamento e da aparição do feminino no e pelo discurso do outro.

Por fim, o próprio Povo conclui com fome de carnificina: "É aquela que na verdade a ninguém se deu, e agora é toda nossa" (p. 184, grifos nossos). Está dito: não houve crime, mas há o castigo. Portanto, quando ao final da peça a criança questiona: "Mamãe, que foi que aconteceu?" (p. 191), a resposta já havia sido dolorosamente dada.

Num mundo em que não há perdão possível para a sentença fatal sobre o não-pecado, a morte surge como único discurso incorporável ao feminino afásico em "A pecadora queimada e os anjos harmoniosos": "Povo: Que fale a que vai morrer. [...] SACERdote: Tomai-lhe a morte como palavra." (p. 188). A oração às avessas em Lídia Jorge encontra, assim, ressonância na peça de Clarice Lispector: o discurso amoroso não redime, o perdão é anulado, o silêncio eterno da morte se torna a única palavra. Se lá pedia-se abafa! para libertar, aqui impele-se morre! para dizer.

\section{O PORO POSSÍVEL}

Se fica claro, como observamos, que as duas personagens foram colocadas impositivamente num espaço de silenciamento, de asfixia existencial, resta sabermos: como respirar? Como dizer neste ambiente opressor? Qual o poro possível? Se ambas foram alocadas numa posição de vítima, também as duas recusam-se a sê-lo. Elas tentam. Num gesto de coragem, ousam desvencilhar-se da fumaça que as persegue, mas jamais diretamente: porque não podem. Por isso as tentativas são enviesadas: a oração pelo avesso, a inserção no discurso do outro, o sorriso escondido, o desprezo pela ideia de pecado, a ajuda da voz narrativa. São caminhos curvos, tortuosos, mas são caminhos, como os de Luiza, de busca de linguagem. Aproxima as duas protagonistas o fato de, fatalmente silenciadas, ambas conseguirem alargar - tanto quanto lhes seria possível - o lugar de emparedamento e submissão ao qual foram obrigadas a permanecer. Não podendo ainda sair da sombra do masculino, a porteira e a pecadora se reafirmam enquanto mulheres - enquanto sujeitos - na máxima medida que conseguem.

À porteira só lhe fora ensinado que uma mulher não é um ser inteiro. Seria incoerente esperar dela uma atitude que combatesse explicitamente essa visão de mundo. Talvez justamente aí esteja o traço que nos comove nesta personagem: ela não luta porque não sabe que pode lutar, e, ainda assim, gaguejantemente, volta-se contra o seu homem. Isto não é pequeno. 
Já a pecadora é tão mais dona do próprio corpo que, da sombra, sorri, avisando à sua plateia - porque é este o verdadeiro papel dos outros personagens, cujos olhos e discursos jamais são desviados daquela mulher - que seu corpo será queimado, mas seu espírito permanecerá intacto e digno. Ironicamente, ainda que ela seja a dita pecadora, são os outros personagens o nosso verdadeiro objeto de julgamento.

Falamos no início deste texto que a semelhança entre as mortes das duas não se restringe à já forte imagem do fogo. A significação de fuga, de libertação, de purificação envolve ambas as histórias. No mundo controlado pelo masculino, a mulher será punida, mas essas protagonistas não são maculadas de culpa: são o retrato do crime do outro. Pela oração às avessas da voz que nunca conseguiu ter como sua, Lúcia consegue ser salva pela mãe, porque só o feminino poderia trazer-lhe redenção. Experimentando os corpos masculinos, também a pecadora-sem-pecado tortuosamente consegue nos mostrar que o verdadeiro crime não foi ela quem cometeu.

Na sua morte inevitável - porque, se são seres de coragem, também o são de falência -, a porteira e a pecadora queimam no fogo do duplo. Enquanto a labareda viril destrói fisicamente as duas mulheres, a chama redentora lava e purifica as suas almas, e se o corpo sofre, também ascende em triunfo final. E se ao lermos o martírio das duas nos sentimos profundamente, também nós, silenciados, é por reconhecermos ali uma dimensão da falta que possivelmente guardamos também dentro de nós.

É diante da concentração da expressão do silêncio dessas mulheres que nós emudecemos, talvez por reconhecê-las em nós. Com elas gaguejamos e tentamos ressurgir da mudez em meio à fumaça e ao fogo que tentam nos abafar fatalmente. Há silêncio, mas, como elas, abrimos um poro possível e reaprendemos a respirar.

\section{REFERÊNCIAS BIBLIOGRÁFICAS}

BARTHES, Roland. Fragmentos de um discurso amoroso. $3^{\text {a }}$ ed. Rio de Janeiro: Francisco Alves, 1981.

COELHO, Jacinto do Prado. A letra e o leitor. $2^{\text {a }}$ ed. Lisboa: Moraes Editores, 1977.

FIGUEIREDO, Monica. No corpo, na casa e na cidade: as moradas da ficção. $1^{\text {a }}$ ed. Rio de Janeiro: Língua Geral, 2011.

JORGE, Lídia. "Marido” In: Marido e outros contos. Lisboa: Publicações Dom Quixote, 1997.

LISPECTOR, Clarice. "A pecadora queimada e os anjos harmoniosos”. In: A legião estrangeira. $1^{\text {a }}$ ed. Rio de Janeiro: Editora do Autor, 1964. 
ORLANDI, Eni Puccinelli. As formas do silêncio: no movimento dos sentidos. $6^{\text {a }}$ ed. Campinas: Editora da UNICAMP, 2007.

QUEIRÓS, Eça de. O primo Basílio. 2a ed. Rio de Janeiro: BestBolso, 2008.

ROUBINE, Jean-Jacques. A linguagem da encenação teatral. $2^{\text {a }} \mathrm{ed}$. Rio de Janeiro: Jorge Zahar Editora, 1998.

Recebido para publicação em 29/11/2012

Aprovado em 26/02/2013

\section{NOTAS}

1 Assim define Monica Figueiredo: "Parte da silenciada (e por isso silenciosa) Luiza a indagação fundadora: 'com que linguagem?' [...] Mas se Luiza aprendeu a conviver com o silêncio, o mesmo não conseguiu fazer com a fala, que para ela nunca ultrapassou a forma gaguejante. Por ser incapaz de transformar o silêncio que impossibilita em pausa significativa na emissão do discurso, ela não foi capaz de sobreviver à doença que silenciou para sempre a sua titubeante busca de significação." (2002, p. 21-22). A longa citação nos parece pertinente por ser justamente uma das chaves da nossa análise.

2 Pela própria natureza (dramática) da obra, não há voz narrativa para falar pela pecadora - o que, aliás, talvez mesmo agrave a sua condição de silenciada. O recurso da peça é apagar a sua condição de sujeito, fazendo-a aparecer somente como objeto do discurso do outro.

$3 \mathrm{Na}$ abertura de seu Fragmentos de um discurso amoroso, Roland Barthes nos diz que o lugar de fala do enamorado é "o lugar de alguém que fala de si mesmo, apaixonadamente, diante do outro (o objeto amado) que não fala” (1998, p. 1). O que flagramos na peça de Clarice não é senão o discurso amoroso do masculino que assume sua culpa e seu próprio pecado diante do feminino emudecido.

4 Relembramos outra vez Monica Figueiredo (2002) e sua proposição de que Luiza (e tantas outras mulheres em Eça de Queirós) foi punida por arriscar sair desse espaço delimitado para a mulher do século XIX e, ainda, que essa ultrapassagem de limites só pôde se dar aos tropeços, com falas e atos gaguejantes - porque Luiza não sabia mover-se naquele espaço masculino que nunca fora realmente seu. 